\title{
The species complex Astyanax fasciatus Cuvier (Teleostei, Characiformes) - a multidisciplinary approach
}

\author{
R. Pazza*†, S. A. F. Kavalco $\$$, P. R. Penteado $\$$, \\ K. F. Kavalco $\|$ and L. F. de Almeida-Toledo $\|$ \\ *Universidade Federal de Viçosa, UFV, Campus Rio Paranaı́ba, Rodovia BR 354, km \\ 310, Campus Universitário, Rio Paranaíba, MG 38810-000, Brazil, \$Faculdade Assis \\ Gurgacz, Av. das Torres, 500, Cascavel, PR, Brazil, §Universidade Estadual do Centro \\ Oeste do Paraná, UNICENTRO, Rua Presidente Zacarias, 875, Guarapuava, PR, Brazil \\ and \|Universidade de São Paulo, USP, Instituto de Biociências, Rua do Matão, 277, \\ Cidade Universitária, São Paulo, SP, Brazil
}

(Received 16 October 2007, Accepted 17 January 2008)

\begin{abstract}
Cytogenetic data have provided important clues that the Astyanax fasciatus populations from the Upper Paraná River basin could be a part of a more diverse fish group, usually included on the same taxa. Samples collected in Cachoeira de Emas, SP, in Mogi-Guaçu River basin, show two major cytotypes presenting $2 n=46$ and $2 n=48$ chromosomes, with distinct karyotypic formula, despite the fact that the molecular data suggested some degree of gene flow between these cytotypes. Cytogenetic and morphometric analyses were performed in this species, aiming to contribute to the understanding of the natural history from such fish group. Two allopatric populations with distinct standard cytotypes were analysed, and the data obtained suggest the separation into two groups.

(C) 2008 The Authors

Journal compilation $(2008$ The Fisheries Society of the British Isles
\end{abstract}

Key words: cytotaxonomy; karyotype diversification; morphometric analysis.

\section{INTRODUCTION}

Different species concepts, based on different premises, have been used in an attempt to recognize the natural boundaries of living organisms. Among them, Mayr's concept, also known as the biological species concept, is the most widely used for living diploid groups having sexual reproduction. Although the description of a new species in practice uses phenotypic characters, increasing the utilization of genetic techniques to access some aspects of the biological species concept, such as the number of migrants per generations (measure of gene flow among populations and/or species) using molecular markers (Ogden \& Thorpe, 2002; Hey et al., 2004; Postma \& von Noordwijk, 2005; Samonte

†Author to whom correspondence should be addressed. Email: rpazza@ufv.br 
et al., 2007; among others) is also beneficial. Taxonomic revisions on the genus Astyanax, for example, have given species status to groups previously classified as sub-species (Melo, 2001) or even sub-groups inside the 'species complexes' (Bertaco \& Lucena, 2006).

Especially in the Astyanax fasciatus Cuvier, 1819, species, morphological analysis (Melo, 2001) favoured giving species status to the samples that occur in Paraíba do Sul River basin, an important drainage system in Southern Brazil, to Astyanax parahybae Eigenmann, 1908 (previously known as Astyanax fasciatus parahybae). Cytogenetic analysis has provided clues that the Upper Paraná River basin populations belong to a more diverse group of fish that nowadays integrate the same taxa (Artoni et al., 2006; Pazza et al., 2006; Gross et al., 2004).

Aiming to contribute to the understanding of the 'fasciatus' group boundaries, samples from Angatuba, SP (Paranapanema River basin) and Araras, SP (Mogi-Guaçu River basin) were analysed. Both of them belong to the Upper Paraná River system. Classic and molecular cytogenetic markers were used, associated with morphometric data analysis. This data integration has provided valuable information, which helps to characterize Neotropical fish species complexes (Moreira-Filho \& Bertollo, 1991; Mizoguchi \& MartinsSantos, 1998; Maistro et al., 1998; Gross et al., 2006).

\section{MATERIALS AND METHODS}

Astyanax fasciatus samples were collected from Araras, SP, Mogi-Guaçu River basin (seven specimens) and Angatuba, SP, Paranapanema River basin (12 specimens) (Fig. 1). Chromosome preparations were made according to Bertollo et al. (1978) and Gold et al. (1990) using the anterior kidney. The nucleolar organizer regions (NORs) and heterochromatin locations were detected according to Kavalco \& Pazza (2004) and Sumner (1972), respectively. Fluorescence in situ hybridization (FISH) was performed according to Pazza et al. (2006) using 18S rDNA (Hatanaka \& Galetti Jr, 2004) and 5S rDNA (Martins \& Galetti Jr, 1999) probes. Chromosomes were classified as metacentric (M), submetacentric (SM), subtelocentric (ST) and acrocentric (A) based on the classification of centromere position by Levan et al. (1964). Fundamental number (FN) was estimated according to chromosome arm numbers.

All of the individuals were measured using a manual calliper of $0.05 \mathrm{~mm}$ precision, following the standard length, head length, head height, body height, tail peduncle height, predorsal distance, pre-anal distance, orbit diameter and interorbital width variables. Discriminant function analysis (Hotelling), neighbour-joining dendrogram based on Bray-Curtis similarity matrix (Bray \& Curtis, 1957) and the size-free canonical discriminant analysis (SF-CDA) aiming to remove the effect of within-group ontogenetic variation (Reis et al., 1990) was performed with the Past v1.67b software (Hammer et al., 2001) based on covariance matrix of log-transformed measurements to assess morphometric variation between samples.

\section{RESULTS}

The Araras population of fish show a 48 chromosome (8M, 22SM, 12ST, 6A and $\mathrm{FN}=90$ ) diploid number [Fig. 1(a)]. Silver nitrate impregnation demonstrated a modal number of two chromosomes bearing Ag-NORs, especially in the distal region of the long arm of acrocentric chromosomes [Fig. 2(a)]. Constitutive heterochromatin was located on the distal regions of the long arms of submetacentric, subtelocentric and acrocentric chromosomes and on 
(a)

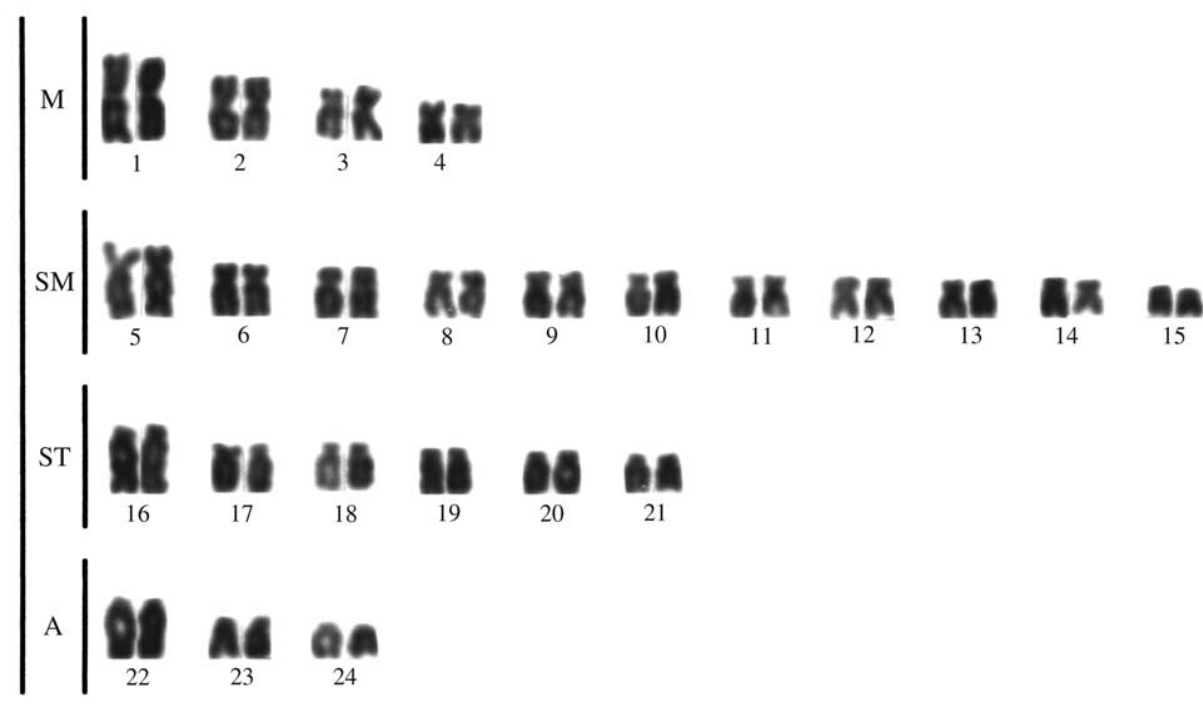

(b)

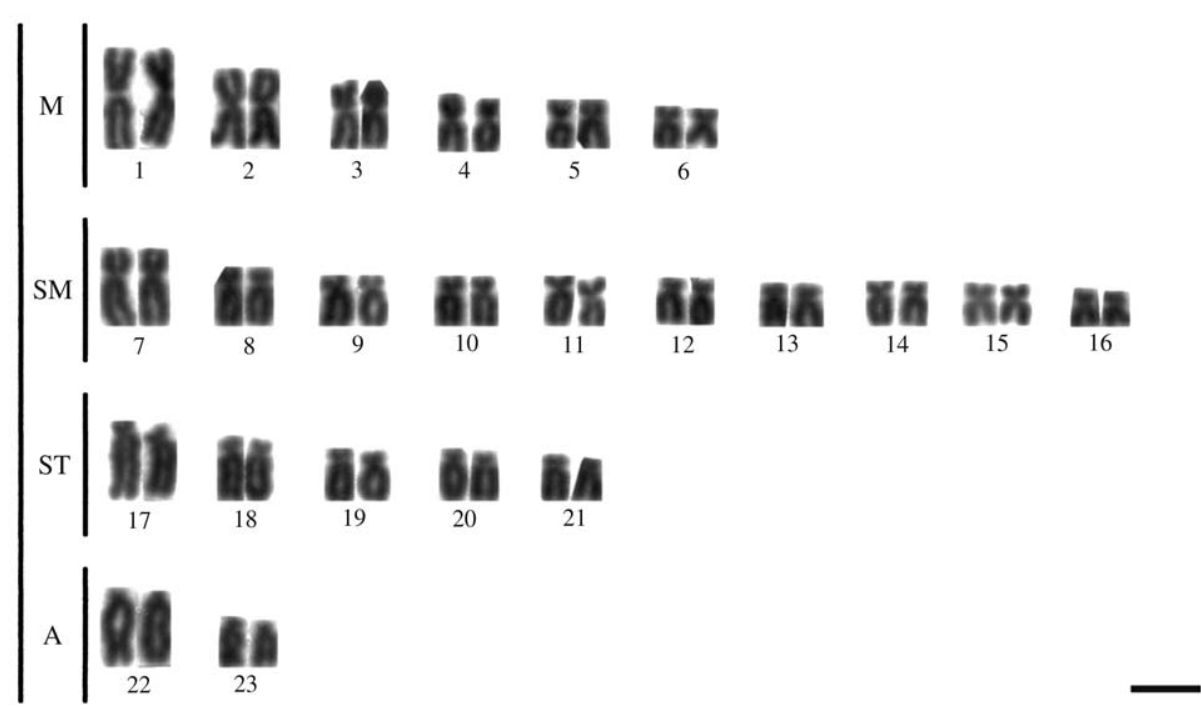

FIG. 1. Karyotypes of Astyanax fasciatus from (a) Araras $(2 n=48)$ and (b) Angatuba $(2 n=46)$ populations. Bar $=10 \mu \mathrm{m}$.

the short arm of some chromosomes [Fig. 2(b)]. FISH revealed two chromosome pairs bearing $5 \mathrm{~S}$ sites, one of them at the pericentromeric region of a metacentric pair and the other one at the proximal region of an acrocentric chromosome [Fig. 2(c)]. In turn, three submetacentric chromosome pairs bearing $18 \mathrm{~S}$ were found; two of them in the terminal region of the short arm and the other one at the terminal region of the long arm [Fig. 2(d)].

The Angatuba population is characterized by a 46 chromosome (12M, 20SM, 10ST, 4A and FN = 88) diploid number [Fig. 1(b)]. Silver nitrate 

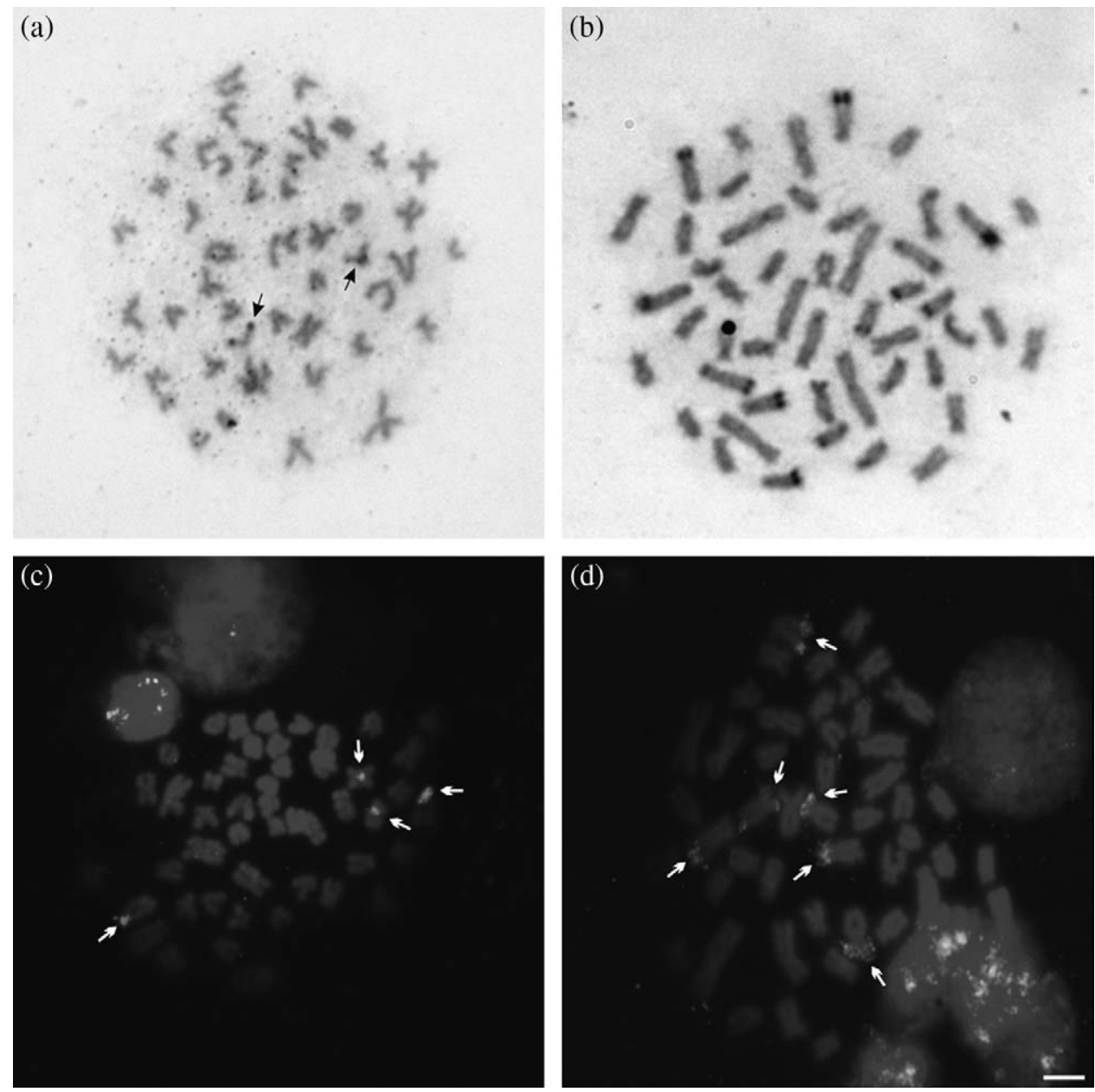

FIG. 2. Astyanax fasciatus metaphases from the Araras population. (a) Ag-NORs, (b) C-banding, (c) 5S fluorescence in situ hybridization (FISH) and (d) 18S FISH. The markers are shown by arrows. Bar $=10 \mu \mathrm{m}$.

impregnation revealed a modal number of four submetacentric chromosomes bearing Ag-NORs in terminal position of the long arms [Fig. 3(a)]. Constitutive heterochromatin was located in the distal region of submetacentric, subtelocentric and acrocentric chromosome long arms [Fig. 3(b)]. FISH revealed two chromosome pairs bearing 5S rDNA sites at the proximal region of a metacentric and an acrocentric chromosome pairs [Fig. 3(c)]. In turn, the $18 \mathrm{~S}$ rDNA sites were located at the terminal region of long arms of two submetacentric chromosome pairs [Fig. 3(d)].

Discriminant analysis made it possible to test the classification of the data in two groups (populations) (Wilk's lambda $=0 \cdot 2068$; Hoteling's $P=0 \cdot 01677$ ). Such analysis shows that one individual from Araras population must belong to the Angatuba population. The withdrawal of this individual permitted an exact classification of individuals according to their populations $(P=0.003)$. 

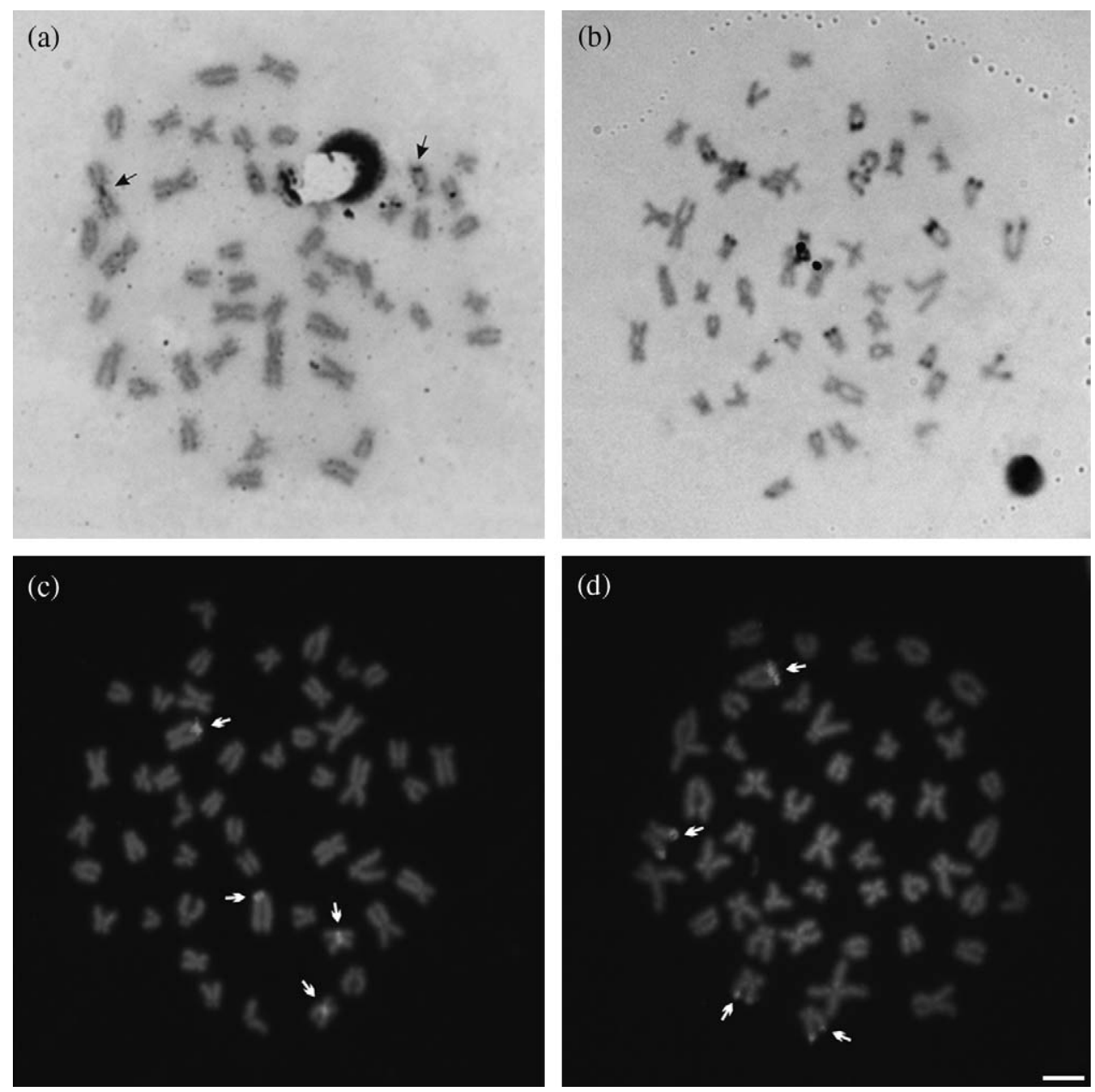

FIG. 3. Astyanax fasciatus metaphases from the Angatuba population. (a) Ag-NORs (left arrow showing a nucleolar organizer region association), (b) C-banding, (c) $5 \mathrm{~S}$ fluorescence in situ hybridization (FISH) and (d) 18S FISH. The markers are shown by arrows. Bar $=10 \mu \mathrm{m}$.

The neighbour-joining dendrogram based on the Bray-Curtis similarity index shows more similarities within Angatuba population (Fig. 4). The SF-CDA clearly separates the populations even when the discrepant individual was considered (Fig. 5).

\section{DISCUSSION}

The karyotypes observed in both populations are quite similar to the previously observed one in the A. fasciatus complex, including the positive C-band distribution, the NORs sites evidenced by silver nitrate impregnation and FISH (Pazza et al., 2006).

The cytogenetic markers show that the genus Astyanax is greatly diversified. It is interesting that this widespread species shows remarkable variation, such 


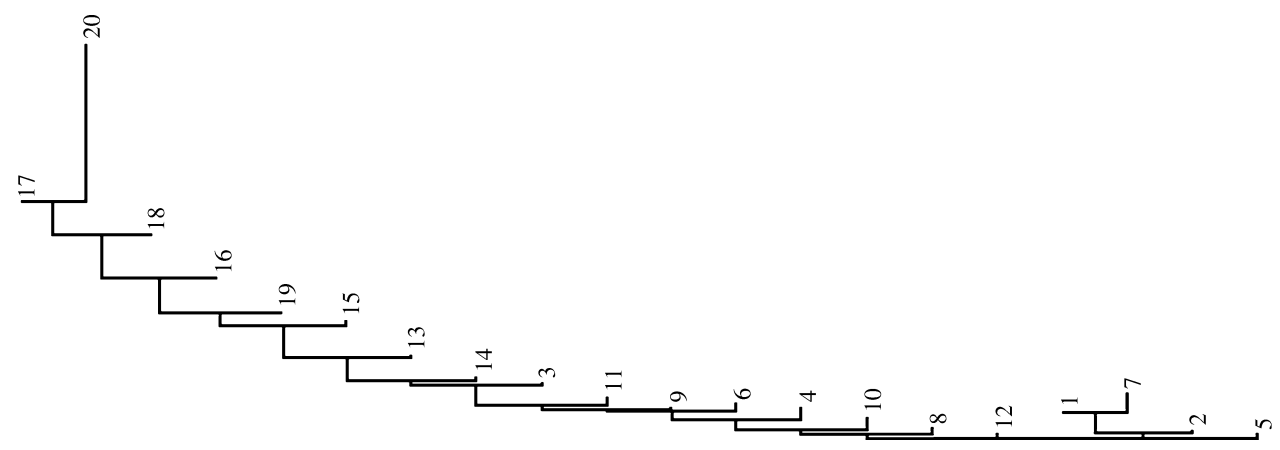

FIG. 4. Neighbour-joining dendrogram based on Bray-Curtis index of similarity. The individuals from Angatuba are represented by 1 to 12 and those from Araras by 13 to 20 .

as the C-bands position and the number and location of NORs-bearing chromosomes (Moreira-Filho \& Bertollo, 1991; Maistro et al., 1998; Mizoguchi \& Martins-Santos, 1998; Pazza et al., 2006; among others). This could be explained by the biological patterns of this group; small fishes with most species inhabitating small streams. Another point is related to the 5S rDNA location, very conserved in most Astyanax species (Almeida-Toledo et al., 2002; Kavalco et al., 2004), especially one proximal site in a metacentric chromosome pair. Such conservation contributes to better understanding of the karyotypic evolutionary aspects of the genus since Astyanax giton Eigenmann, 1908 and

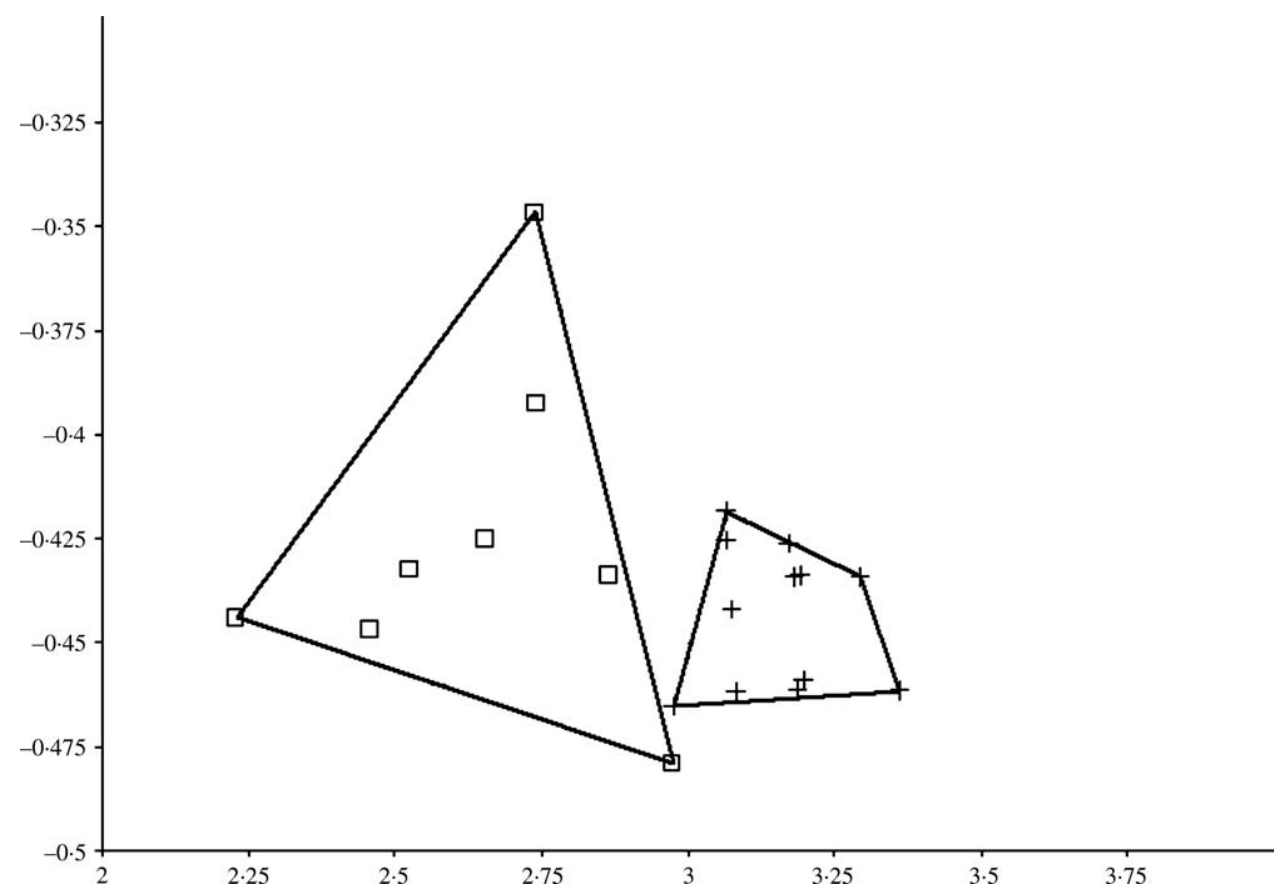

FIG. 5. Size-free canonical discriminant analysis plot showing Angatuba (cross) and Araras (square) populations. 
Astyanax intermedius Eigenmann, 1908 species present a divergent picture, with several 5S rDNA-bearing chromosomes (Kavalco et al., 2004).

In spite of macrokaryotypic differences (chromosome number and type), the analysed populations share characteristics with other A. fasciatus populations (Pazza et al., 2006), such as C-band distribution in the terminal region of several chromosomes, submetacentric chromosomes bearing NORs with terminal sites shown by silver nitrate and $18 \mathrm{~S}$ rDNA FISH and the location of $5 \mathrm{~S}$ rDNA sites as well.

Considering the Astyanax genus karyotypic diversity, such patterns should reflect the evolutionary history of the group and their distribution throughout the Paraná River basin as such basin drains a great area of the Brazilian territory. However, the time of divergence seems to have permitted a certain degree of chromosomal differentiation. Although the role of chromosomal variation in the speciation process is an open question, the correlation between the karyotypic differences and the morphometric analysis between such populations is remarkable. As is observed in some Astyanax scabripinnis (Jenyns, 1842) (MoreiraFilho \& Bertollo, 1991; Maistro et al., 1998; Mizoguchi \& Martins-Santos, 1998) populations, both $A$. fasciatus populations in this study could be discriminated by their chromosome and morphometric patterns.

A similar study was performed with Astyanax populations (recently identified as Astyanax aff. fasciatus) from Tibagi River and the Furnas of Vila Velha State Park (Paraná State) (Artoni et al., 2006). The Furnas are three collapsed wells called 'sinkholes', formed in the Pleistocene. The wells contain water levels reaching the groundwater and no direct communication between them or with other bodies of water, allowing them to be considered as regions of endemism for Astyanax (Artoni \& Almeida, 2001). The canonical discriminant analysis shows significant differentiation among isolated populations (Shibatta \& Artoni, 2005; Artoni et al., 2006). The Astyanax populations of these sites show a remarkable karyotypic variability, characterized by at least three cytotypes (Artoni et al., 2006). Unfortunately, the authors did not perform the canonical analysis using the cytotypes as grouping factor since there are some cytotypes distributed among more than one silkhole; meanwhile, there are sympatric cytotypes in others. Indeed, the cytotype identified as 'A' is widespread on Tibagi River and other sites studied by the authors, including the sinkhole 2, which was strongly separated by canonical analysis (Artoni et al., 2006). Nevertheless, the fluctuating asymmetry from sinkhole 2 did not differ from Tibagi River population (Gross et al., 2004).

The cytogenetic data obtained in the present work reinforce the hypothesis previously suggested for the A. fasciatus cytotypes distribution in Paraná River basin (Pazza et al., 2006). The authors found a chromosome polymorphism in the Cachoeira de Emas region of the Mogi-Guaçu River, where, besides the standard cytotypes (with correct homologous pairing) with $2 n=46$ and $2 n=48$ chromosomes, one $2 n=45$ variant, another with $2 n=46$ and four $2 n=47$ cytotypes were found in sympatry. Additionally, the frequency of $2 n=46$ chromosomes was higher in this region than that observed in the upper and lower Mogi-Guaçu River, which should suggest an invasive species with the $2 n=46$ cytotypes, $2 n=48$ being the native one (Pazza et al., 2006), although the molecular data suggests a certain degree of gene flow among the cytotypes, possibly 
resulting from a secondary contact (Pazza et al., 2007). The present data reinforces such a hypothesis with the individuals from the Araras site possessing the same karyotypic patterns as observed in the $2 n=48$ cytotype from Mogi-Guaçu River. Additionally, the presence of one individual with divergent morphometric data is notable, and it is possible that this one results from secondary contact introgression as evidenced by molecular markers (Pazza et al., 2007).

The use of the genetic analysis technologies throws light on questions about the natural history of the species. However, traditional analyses such as cytogenetic and morphometric methods can still contribute, especially when it is necessary to identify species in the field.

The authors are grateful to Fundação de Amparo ā Pesquisa do Estado São Paulo for financial support.

\section{References}

Almeida-Toledo, L. F., Ozouf-Costaz, C., Foresti, F., Bonilo, C., Porto-Foresti, F. \& Daniel-Silva, M. F. Z. (2002). Conservation of the 5S-bearing chromosome pair and co-localization with major rDNA clusters in five species of Astyanax (Pisces, Characidae). Cytogenetic and Genome Research 97, 229-233.

Artoni, R. F. \& Almeida, M. C. (2001). A singular diversidade dos peixes dos Campos Gerais: uma visão genética para abordagem conservacionista da região. In: Espaço e Cultura: Ponta Grossa e os Campos Gerais (Ditzel, C. H. M. \& Sahr, C. L. L., eds), 518p. Ponta Grossa: Editora UEPG.

Artoni, R. F., Shibatta, O. A., Gross, M. C., Schneider, C. H., Almeida, M. C., Vicari, M. R. \& Bertollo, L. A. C. (2006). Astyanax aff. fasciatus Cuvier, 1819 (Teleostei; Characidae): evidences of a species complex in the upper rio Tibagi basin (Paraná, Brazil). Neotropical Ichthyology 4, 1997-2002.

Bertaco, V. A., \& Lucena, C. A. S. (2006). Two new species of Astyanax (Ostariophysi: characiformes: characidae) from eastern Brazil, with a synopsis of the Astyanax scabripinnis species complex. Neotropical Ichthyology 4, 53-60.

Bertollo, L. A. C., Takahashi, C. S. \& Moreira-Filho, O. (1978). Cytotaxonomic considerations on Hoplias lacerdae (Pisces, Erythrinidae). Revista Brasileira de Genética 1, 103-120.

Bray, J. R. \& Curtis, J. T. (1957). An ordination of the upland forest communities of southern Wisconsin. Ecological Monographs 27, 325-349.

Gold, J. R., Li, C., Shipley, N. S. \& Powers, P. K. (1990). Improved methods for working with fish chromosomes with a review of metaphase chromosome banding. Journal of Fish Biology 37, 563-575.

Gross, M. C., Schneider, C. H., Almeida, M. C., Leite, M. L., Bertollo, L. A. C. \& Artoni, R. F. (2004). Population structure, fluctuating asymmetry and genetic variability in an endemic and highly isolated Astyanax sp. fish population (Characidae). Genetics and Molecular Biology 27, 529-535.

Hammer, O., Harper, D. A. T. \& Ryan, P. D. (2001). PAST: palaeontological statistics software package for education and data analysis. Palaeontologia Electronica 4, 9.

Hatanaka, T. \& Galetti Jr, P. M. (2004). Mapping of the $18 \mathrm{~S}$ and 5 S ribosomal RNA genes in the fish Prochilodus argenteus Agassiz, 1829 (Characiformes, Prochilodontidae). Genetica 122, 239-244.

Hey, J., Won, Y. J., Sivasundar, A., Nielsen, R. \& Marker, J. A. (2004). Using nuclear haplotypes with microsatellites to study gene flow between recently separated Cichlid species. Molecular Ecology 13, 909-919.

Kavalco, K. F. \& Pazza, R. (2004). A rapid alternative technique for obtaining silverpositive patterns in chromosomes. Genetics and Molecular Biology 27, 196-198. 
Kavalco, K. F., Pazza, R., Bertollo, L. A. C. \& Moreira-Filho, O. (2004). Gene mapping of 5S rDNA sites in eight fish species from the Paraíba do Sul river basin, Brazil. Cytogenetic and Genome Research 106, 107-110.

Levan, A., Fredga, K. \& Sandberg, A. A. (1964). Nomenclature for centromeric position on chromosomes. Heriditas 52, 201-220.

Maistro, E. L., Oliveira, C. \& Foresti, F. (1998). Comparative cytogenetic and morphological analysis of Astyanax scabripinnis paranae (Pisces, Characidae, Tetragonopterinae). Genetics and Molecular Biology 21, 201-206.

Martins, C. \& Galleti Jr, P. M. (1999). Chromosomal localization of 5S rDNA genes in Leporinus fish (Anostomidae, Characiformes). Chromosome Research 7, 363-367.

Melo, F. A. G. (2001). Revisão taxonômica das espécies do gênero Astyanax Baird e Girard, 1854 (Teleostei: Characiformes: Characidae) da região da Serra dos Órgãos. Rio de Janeiro. Arquivos do Museu Nacional do Rio de Janeiro 59, 1-46.

Mizoguchi, S. M. H. N. \& Martins-Santos, I. C. (1998). Cytogenetic and morphometric differences in populations of Astyanax "scabripinnis" (Pisces Characidae) from Maringá region, PR, Brazil. Genetics and Molecular Biology 21, 55-61.

Moreira-Filho, O. \& Bertollo, L. A. C. (1991). Astyanax scabripinnis (Pisces, Characidae): a species complex. Genetics and Molecular Biology 14, 331-357.

Ogden, R. \& Thorpe, R. S. (2002). Molecular evidence for ecological speciation in tropical habitats. Proceedings of National Academy of Science 99, 13612-13615.

Pazza, R., Kavalco, K. F. \& Bertollo, L. A. C. (2006). Chromosome Polymorphism in Astyanax fasciatus (Teleostei, Characidae). I - Karyotypic analysis, Ag-NORs and mapping of the $18 \mathrm{~S}$ and $5 \mathrm{~S}$ ribosomal genes in sympatric karyotypes and their possible hybrid forms. Cytogenetic and Genome Research 112, 313-319.

Pazza, R., Kavalco, K. F., Prioli, S. M. A. P., Prioli, A. J. \& Bertollo, L. A. C. (2007). Chromosome polymorphism in Astyanax fasciatus (Teleostei, Characidae), Part 3: analysis of the RAPD and ISSR molecular markers. Biochemical Systematics and Ecology 32, 843-851.

Postma, E. \& von Noordwijk, A. J. (2005). Gene flow maintains a large genetic difference in clutch size at a small spatial scale. Nature 433, 65-68.

Reis, S. F., Pessôa, L. M. \& Strauss, R. E. (1990). Application of size-free Canonical Discriminant Analysis to studies of geographic differentiation. Brazilian Journal of Genetics 13, 509-520.

Samonte, I. E., Satta, Y., Sato, A., Tichy, H., Takahata, N. \& Klein, J. (2007). Gene flow between species of Lake Victoria haplochromine fishes. Molecular Biology and Evolution 24, 2069-2080.

Shibatta, O. A. \& Artoni, R. F. (2005). Sobre a identidade das populações alopátricas de Astyanax (Characiformes, Characidae) das formações Furna 1 e Furna 2 do Parque Estadual de Vila Velha, Ponta Grossa, Paraná, Brasil. Publicações UEPG Ciências Biológicas e Saúde, Ponta Grossa 11, 7-12.

Sumner, A. T. (1972). A simple technique for demonstrating centromeric heterocromatin. Experimental Cell Research 75, 304-306. 